\title{
Review \\ Platelet-Rich Plasma Applications for Achilles Tendon Repair: A Bridge between Biology and Surgery
}

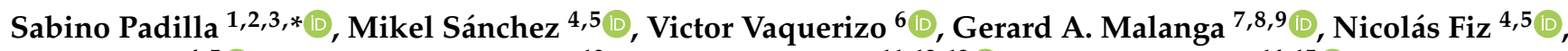 \\ Juan Azofra 4,5 (D), Christopher J. Rogers ${ }^{10}$, Gonzalo Samitier 11,12,13 (D), Steven Sampson 14,15 (D), \\ Roberto Seijas ${ }^{11,12,13} \mathbb{D}^{\text {, Ricardo Elorriaga }}{ }^{16} \mathbb{D}^{1}$, Jack Taunton ${ }^{17}$, Frank Boehm ${ }^{18}$, Roberto Prado ${ }^{1,2,3} \mathbb{1}^{1}$, \\ Ramón Cugat $11,12,13$ and Eduardo Anitua $1,2,3, * \mathbb{D}$
}

check for updates

Citation: Padilla, S.; Sánchez, M.; Vaquerizo, V.; Malanga, G.A.; Fiz, N.; Azofra, J.; Rogers, C.J.; Samitier, G.; Sampson, S.; Seijas, R.; et al.

Platelet-Rich Plasma Applications for Achilles Tendon Repair: A Bridge between Biology and Surgery. Int. J. Mol. Sci. 2021, 22, 824. https://doi. org/10.3390/ijms22020824

Received: 23 December 2020 Accepted: 10 January 2021 Published: 15 January 2021

Publisher's Note: MDPI stays neutral with regard to jurisdictional clai$\mathrm{ms}$ in published maps and institutional affiliations.

Copyright: (C) 2021 by the authors. Licensee MDPI, Basel, Switzerland. This article is an open access article distributed under the terms and conditions of the Creative Commons Attribution (CC BY) license (https:// creativecommons.org/licenses/by/ $4.0 /)$
1 Eduardo Anitua Foundation for Biomedical Research, Jacinto Quincoces, 39, 01007 Vitoria, Spain; roberto.prado@bti-implant.es

2 BTI-Biotechnology Institute ImasD, Jacinto Quincoces, 39, 01007 Vitoria, Spain

3 University Institute for Regenerative Medicine \& Oral Implantology-UIRMI (UPV/EHU-Fundación Eduardo Anitua), Jacinto Quincoces, 39, 01007 Vitoria, Spain

4 Arthroscopic Surgery Unit, Hospital Vithas Vitoria, Beato Tomás de Zumarraga 10, 01008 Vitoria-Gasteiz, Spain; mikel.sanchez@ucatrauma.com (M.S.); nicolas.fiz@ucatrauma.com (N.F.); juan.azofra@ucatrauma.com (J.A.)

5 Advanced Biological Therapy Unit, Hospital Vithas Vitoria, 01008 Vitoria-Gasteiz, Spain

6 Department of Orthopaedic Surgery, Príncipe de Asturias University Hospital, 28805 Alcalá de Henares, Spain; vaquerizovictor@yahoo.es

7 New Jersey Regenerative Institute LLC, Cedar Knolls, NJ 07927, USA; gmalangamd@hotmail.com

8 Department of Physical Medicine and Rehabilitation, Rutgers School of Biomedical and Health Sciences, Newark, NJ 07901, USA

9 Rutgers University and New Jersey Regenerative Medicine Institute, Cedar Knolls, NJ 07927, USA

10 San Diego Orthobiologics Medical Group, Inc., Carlsbad, CA 92011, USA; rogers@sdomg.com

11 Instituto Cugat, Plaza Alfonso Comín 5-7, Planta (-1), 08023 Barcelona, Spain;

samitier@sportrauma.com (G.S.); seijastraumatologia@gmail.com (R.S.); ramon.cugat@sportrauma.com (R.C.)

12 Fundación García Cugat, c/Madrazo 43, 08006 Barcelona, Spain

13 Hospital Quirónsalud Barcelona, Plaza Alfonso Comín 5, 08023 Barcelona, Spain

14 David Geffen School of Medicine at UCLA, 10833 Le Conte Ave, Los Angeles, CA 90095, USA; drsampson@orthohealing.com

15 The Orthohealing Center, 10780 Santa Monica Blvd, Suite 210, Los Angeles, CA 90025, USA

16 Servicio de Cirugía Ortopédica y Traumatología, Hospital Universitario de Basurto, Montevideo Etorb, 18, 48013 Bilbao, Spain; rielorriaga@gmail.com

17 Division of Sports Medicine, Allan McGavin Sports Medicine Centre, University of British Columbia, Chan Gunn Pavilion 2553 Wesbrook Mall, Vancouver, BC V6T 1Z3, Canada; jack.taunton@ubc.ca

18 NanoApps Medical, Inc., Vancouver, BC V6K 1C8, Canada; frankboehm@nanoappsmedical.com

* Correspondence: sabinopadilla@hotmail.com (S.P.); eduardo@fundacioneduardoanitua.org (E.A.); Tel.: +34-945-160-653 (S.P.)

Abstract: Achilles tendon ruptures are very common tendon ruptures and their incidence is increasing in modern society, resulting in work incapacity and months off sport, which generate a need for accelerated and successful therapeutic repair strategy. Platelet-rich plasma (PRP) is emerging as adjuvant human blood-derived constructs to assist Achilles tendon rupture treatment. However, myriad PRP preparation methods in conjunction with poor standardization in the modalities of their applications impinge on the consistent effectiveness of clinical and structural outcomes regarding their therapeutic efficacy. The purpose of this review is to provide some light on the application of PRP for Achilles tendon ruptures. PRP has many characteristics that make it an attractive treatment. Elements such as the inclusion of leukocytes and erythrocytes within PRP, the absence of activation and activation ex vivo or in vivo, the modality of application, and the adjustment of PRP $\mathrm{pH}$ can influence the biology of the applied product and result in misleading therapeutic conclusions. The weakest points in demonstrating their consistent effectiveness are primarily the result of myriad PRP preparation methods and the poor standardization of modalities for their application. Selecting the right biological scaffold and applying it correctly to restitutio ad integrum of ruptured Achilles tendons remains a daunting and complex task. 
Keywords: Achilles; platelet-rich plasma; PRGF; tendon

\section{Introduction}

Achilles tendon rupture is a common tendon rupture and its incidence is increasing in modern society due to an aging population, the increasing prevalence of obesity, and expanded participation in sports [1]. Affecting the working population and recreational and professional athletes, Achilles tendon ruptures result in work incapacity and many months off sport, creating a significant requirement for accelerated and successful repair, while minimizing fibrosis and functional limitations [1-3]. Achilles tendinopathy is a painful and dysfunctional condition encompassing pathologies ranging from tendinosis or tendinitis to partial and full-thickness tears, where evidence is mounting that points to immunocompetent cells and activated stromal fibroblasts as the drivers of a non-resolved inflammatory condition [4-7]. Platelet-rich plasma (PRP) is emerging as an enhancer of the natural tendon healing process in the conservative and surgical treatment of Achilles tendon ruptures $[2,3,8-10]$. However, a lingering controversy exists as to whether these autologous blood-derived products are efficacious and facilitate expedited Achilles tendon repair [11-15]. The weakest points in demonstrating their consistent effectiveness are primarily the result of myriad PRP preparation methods and the poor standardization of modalities for their application. These elements somehow hamper advancement and lead to contradictory conclusions regarding their therapeutic efficacy $[12,14,16]$.

This narrative review is intended to shed some light on the application of PRP for Achilles tendon ruptures. It endeavors to bring a number of pitfalls into focus regarding the varied methods used in PRP generation and the poor standardization of application modalities.

\section{Aligning Coagulation and Hemostasis with Therapeutic Needs: PRP Products}

Recent work toward deciphering the roles of blood components and of the biochemical machinery underlying the humoral and cellular arms of intravascular innate immune cascade systems, specifically coagulation and hemostasis as well as blood anticoagulation and deconstruction, have led to procedures that filter out platelets and the coagulation machinery to yield PRP [17]. These blood-derived products consist of fluid phase plasma, where platelets, white cells, and red cells are suspended in different concentrations, depending on the specific centrifugation and fractionation processes carried out [18].

\subsection{When Fibrin Meets Growth Factors}

When sodium citrate is used as an anticoagulant, the ex vivo recalcification of the fluid phase with $\mathrm{CaCl}_{2}$ reverts the coagulation cascade, which generates trace amounts of native thrombin that simultaneously induces the activation of platelets and their degranulation and the polymerization of plasma fibrinogen into a progressively functionalized insoluble fibrin matrix $[17,19]$. The newly functionalized three-dimensional fibrin nanoscaffold will bind in a non-diffusible manner and trap several platelet- and plasma-derived growth factors (GFs), chemokines, cytokines, and other biomolecules (TGF $\beta 1$ and $\beta 2$, VEGF, PDGF, FGF, EGF, CTGF, SDF-1 $\alpha$ HGF, IGF1, FXII, IL-8, and C3, among others) through the heparin sulfate proteoglycan domains of adhesive proteins, including fibrinogen, fibronectin (Fn), vitronectin (Vn), and TSP-1 [20-23]. Nevertheless, several GFs, in a diffusible mode, will directly connect with their cognate cell surface receptors (Figure 1A) to induce an immediate effect [22]. 


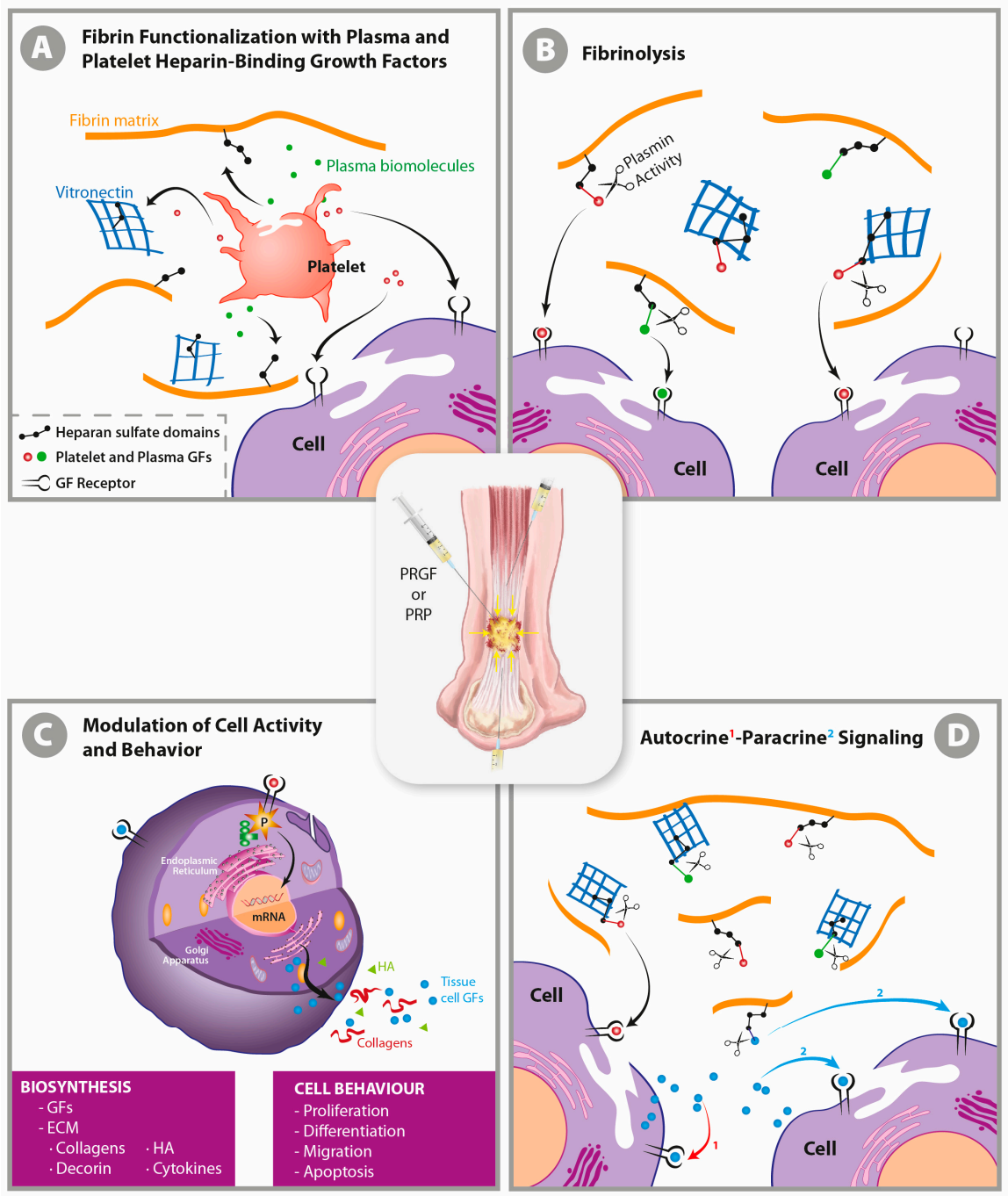

Figure 1. An autologous liquid-to-gel dynamic scaffold as a carrier of biological mediators in tissue repair. When liquid plasma rich in growth factors (GFs) is applied directly into tissue, the newly formed three-dimensional matrix clot traps many of the released growth factors and cytokines from platelet degranulation and from plasma by binding them to the heparin sulfate proteoglycan domains of fibrin matrix components in a non-diffusible mode (yuxtacrine or matricrine) (A). However, some GFs in a diffusion mode (autocrine and paracrine) will directly reach their cognate cell-surface receptor (D), thereby inducing an immediate cell-biosynthetic and cell-behavior modification (C). The ensuing progressive biodegradation of a fibrin clot is mediated by the serine protease plasmin, which is yielded through both the activation of plasminogen by a tissue plasminogen activator [24] and the immune and mesenchymal cells that migrate into the clot, thereby matching the speed of the ingrowing repair tissue $[17,21,22,25,26]$ (B). GFs act as extracellular ligands by binding to transmembrane receptors arrayed on the surface of target cells, thereby activating intracellular signal transduction pathways that convey the signal to the nucleus to eventually induce a wide range of cell specifications during inflammation and the repair process including cell survival, proliferation, migration, differentiation, and maturation and changes in protein synthesis and metabolism (C). These effects include the synthesis and secretion of GFs and cytokines, which interact with their receptors in a diffusible manner (autocrine and paracrine pathways); the synthesis of extracellular matrix (ECM) components such as collagens, decorin, hyaluronic acid, and glycosaminoglycans; and cell survival, proliferation, differentiation, and migration (C) [17]. Only by understanding the unbreakable link between GFs and fibrin matrix will we grasp the in situ biological function of PRP and the additional pivotal fact that it is not necessary to combine this product with other delivery systems to slowdown the release of GFs. 
In PRP, the architectural keystone is the fibrin matrix, as fibrin transiently binds several GFs, transports GFs to the vicinity of cells, and facilitates their tissue penetration, spatial localization, and in situ delivery (Figure 2) [17,21,27]. Moreover, fibrin circumvents the short GF half-life, and not only protects GFs from proteolysis, but also serves as a sink for morphogens and dampens the surge of GFs initially released by platelets (in conjunction with cytokines from leukocytes and the heme iron from erythrocytes, if present), thereby avoiding the bolus effect (Figure 2) [20,22,23,25,28]. Once an autologous fibrin scaffold has been applied, the breakdown of the matrix by tissue fibrinolysis (Figure 1B) releases GFs both immediately and in a gradual and delayed manner. Therefore, PRP operates as a biomimetic biphasic GF delivery systems, while modulating the spatiotemporal chemotactic gradients of the GFs required to induce cell-cell survival, migration, proliferation, differentiation, maturation, and correct orientation in nascent tissues (Figure 1B) [20,27]. The GFs released by platelets (among other tissue-resident cells of damaged areas) are biochemical signaling agents that operate on specifically limited length and time scales in autocrine and paracrine modes (Figure 1D). They diffuse over distances of less than several tens of micrometers; thus their signal intensity decays more than linearly with the distance from the source, roughly $1 / \mathrm{r}^{2}$; in $3 \mathrm{D}$, it is even more rapid [29].

\section{Autologous fibrin matrix as adjunct in tissue engineering and cell therapy in regenerative medicine}

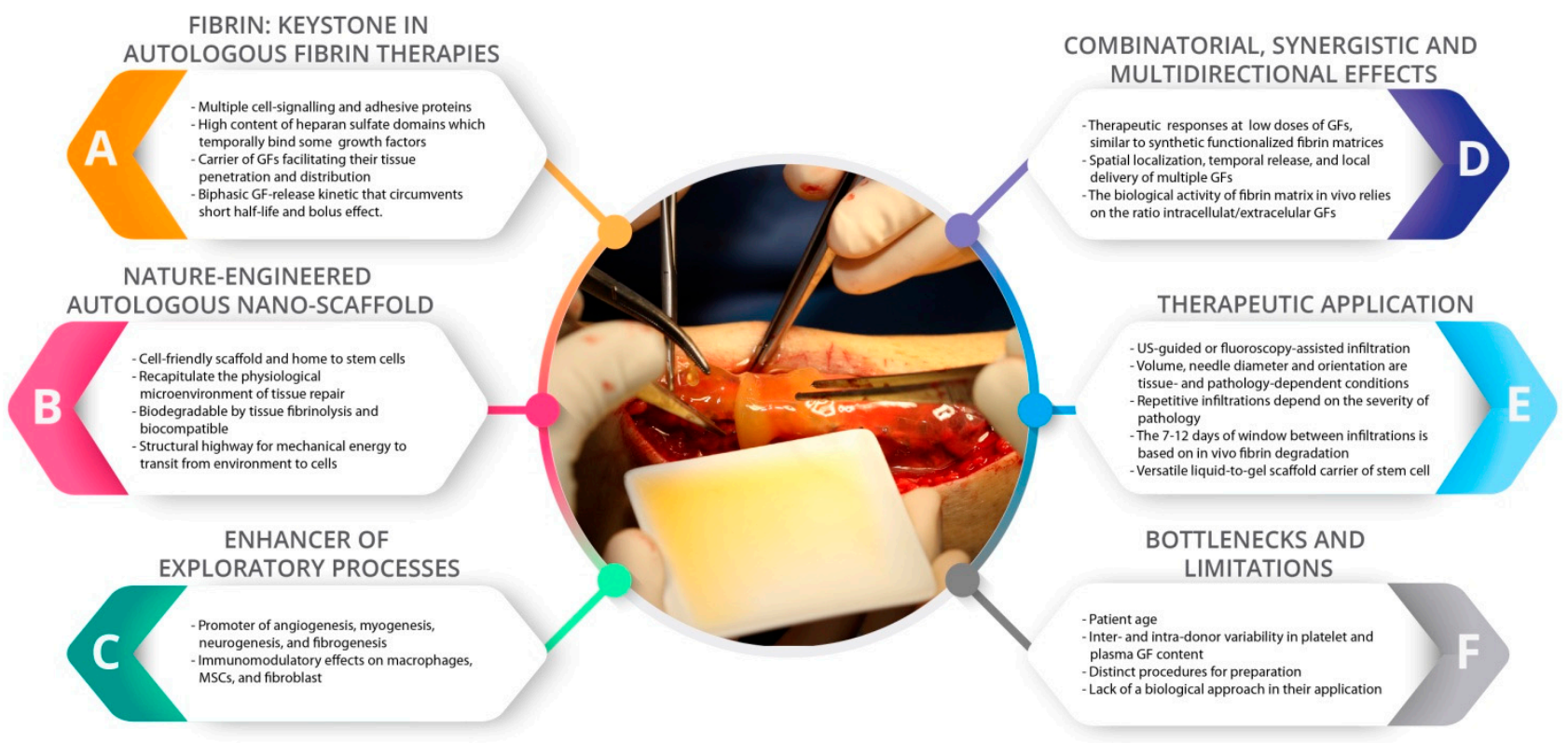

Figure 2. Summary of the primary biological and therapeutic features of platelet-rich plasma (PRP). PRP has emerged as an adjuvant human blood-derived constructs to assist tissue engineering and cell therapies in regenerative medicine. Figure adapted from [17] with permission.

\subsection{Tendon Tissue Effects of PRP: Multi-Directional Role of Growth Factors}

PRP is a biodegradable autologous multi-growth factor scaffold product whose biological effect primarily relies on tissue-resident cells as the pivotal target of GFs conveyed by the fibrin liquid-to-gel dynamic scaffold. Ample evidence based on in vitro, in vivo, and clinical trials indicates that GFs, which are present within PRP and PRP products themselves, exert multi-directional biological effects on the mechanisms that govern tendon tissue repair, including (but not limited to) the following effects: angiogenic [30,31]; antiapoptotic, tenogenic, and proliferative [32-34]; chemotactic, trophic, and biosynthetic [9,30-36]; immunomodulatory and anti-inflammatory [34]; antifibrotic [3,30,31], antialgic [37,38]; and biomechanical $[16,39,40]$. If we focus on the effect of PRP on the extracellular matrix of 
rotator cuff tendons, Cross et al. [35] showed, in an elegant study, that leukocyte-free PRP stimulated normal collagen matrix synthesis (the ratio of COL1A1:COL3A1 gene expression) and decreased the cytokines associated with matrix degradation and inflammation, such as Matrix Metalloproteinases (MMP-9 and MMP-13) and IL-1 $\beta$. These results were also confirmed by Yan et al. [36], demonstrating increased gene expression of Collagen 1 in PRP-treated Achilles tendons and decreased expression of catabolic proteins such as MMP-1 and MMP-3.

In the context of tissue development, regeneration, and repair processes, GFs behave in a combinatorial, synergistic, and multi-directional manner [41], which has inspired regenerative human-engineered approaches [21,22,41]. Accordingly, many successful strategies for therapeutic tissue regeneration and repair integrate a combination of several recombinant GFs that are frequently embedded in a fibrin scaffold [21,27], although in higher doses than the equivalent native growth factors present within autologous fibrin scaffolds [17]. Moreover, GFs within PRP fibrin matrices circumvent some of the drawbacks imposed by recombinant GFs, including their short half-life and bioavailability, high systemic toxicity, bolus effect, rapid cellular internalization rate, the limited spatial and time scales within which they operate, and the requirement of high therapeutic doses [22,28].

\subsection{Practical Considerations in the Application of PRP for Achilles Tendon Ruptures}

Our recommended conservative treatment of Achilles tendon ruptures (Figure 3A-C) usually begins with a dynamic ultrasound study, which should assess and verify that both ends of the rupture will approach each other during plantar flexion (evaluating their mobility), meaning that both extremes might heal effectively without excessive elongation [42]. Once the treatment strategy has been confirmed and is under ultrasound control, and with the foot plantar flexed, 6-8 $\mathrm{mL}$ of a liquid PRGF formulation is percutaneously infiltrated into the center of the rupture. In addition, $4 \mathrm{~mL}$ of liquid PRGF is infiltrated into each of the proximal and distal ends of the tendon (hyperechogenic ultrasound image of PRGF) [42] to recruit tendon and mesenchymal stem cells, as well as to target the stromal inflammatory microenvironment and stromal cell phenotypes, including macrophages and fibroblasts (Figure 3C) [5,43-45]. This infiltration process should be repeated over three consecutive weeks. The patient's ankle is immobilized using a Walker-type orthosis in plantar flexion (equinus), which allows for partial and progressive loading. The equinus of the orthosis is progressively reduced from Week 4 onwards, removing a wedge every week until final removal of the orthosis. An ultrasound examination should be performed in Week 4 after the final infiltration. If unrepaired rupture regions are detected, the injured zone should be infiltrated again. Ultrasound examinations should be repeated every 4 weeks, together with dynamic testing until complete healing of the rupture is confirmed [42]. 

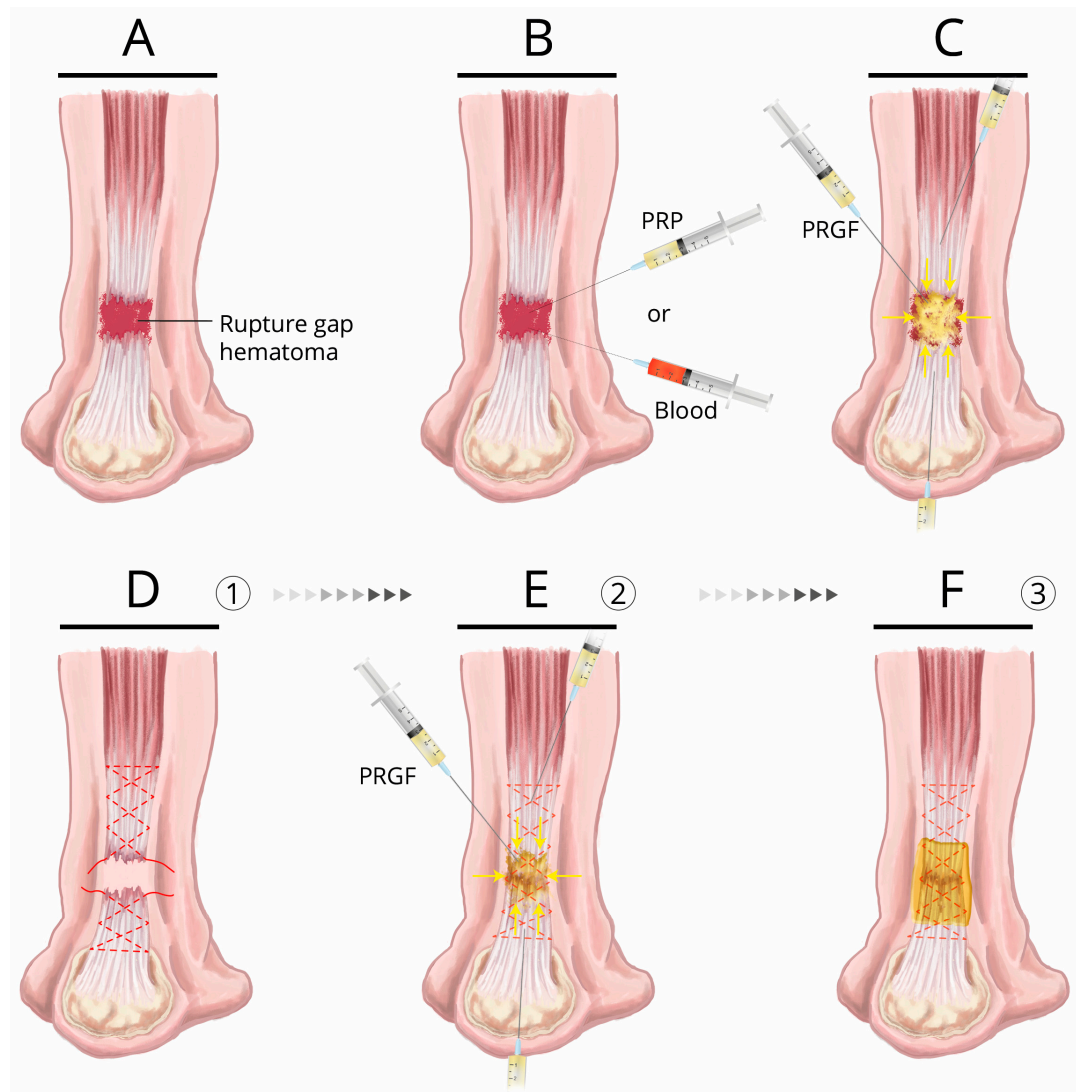

Figure 3. Achilles tendon rupture treatment: conservative and surgical treatment assisted by autologous blood or blood-derived products (PRP). (A) Achilles tendon rupture, rupture gap, and hematoma. (B) Conservative treatment: a single injection of either PRP or autologous blood injected into the gap hematoma. (C) Conservative treatment proposal (in patients with a low functional demand, or for whom surgery is contraindicated). Ultrasound-guided injection of $4 \mathrm{~mL}$ of liquid plasma rich in growth factors (PRGF) in close proximity to the apparently healthy tendon tissue at each stump of the tendon and 4-6 mL of liquid PRGF into the gap hematoma; a procedure to be repeated over 2 or 3 consecutive weeks (D-F) Surgical treatment proposal: after the suture is performed with a non-reabsorbable suture material that has been bathed in liquid PRGF (D), 4-6 mL of liquid PRGF is injected in close proximity to the apparently healthy tendon tissue at each stump, as well as into the sutured area (E) within the time window of 10 to 15 min following PRGF activation with $\mathrm{CaCl}_{2}$. This window encompasses the time when the fibrin scaffold is still macroscopically liquid is but undergoing microscopic jellification. Liquid PRGF can extensively permeate through areas that surround the injection site and anchor to the collagen and other ECM proteins exposed in damaged tissue margins through the activated platelets conveyed by the fibrin clot, as a 3D fibrin-extracellular matrix-like malleable structure [17], thereby bridging the gap of injured areas. The time window of 1-5 $\mathrm{min}$ is the result of the gel point or clotting time, meaning the change from liquid to solid undergone by the matrix when $15-20 \%$ of the fibrinogen has been incorporated into the gel by branching points (approximately $4 \mathrm{~min} 50 \mathrm{~s}$ ) [46]. After closing the paratenon and prior to closing the overlying skin, the peritendinous regions are also infiltrated with PRGF; finally, the entire affected area of the tendon is covered with a fibrin membrane of PRGF $(\mathbf{F})$. As general recommendation, we suggest the use of $10 \mathrm{~mL}$ Luer lock-type syringes with $21 \mathrm{G}$ needles, since the use of small syringes means that large pressures are exerted on the ECM of the tissue during infiltration, thereby accounting for the focalized disruption of the ECM components (a desirable effect in some treatment protocols aimed at disrupting the neovascularization and neoinnervation present in some chronic tendinopathies) [7,42]. Upon infiltration, the needle should be oriented as closely as possible parallel to, and longitudinal with, the tendon fascicles for an optimal diffusion of PRGF [42]. 
For the surgical treatment (recommended for recreational and professional athletes, for whom accelerated functional recovery is essential), the hematoma is evacuated, and the tendon edges are debrided. The tendon is sutured using a non-resorbable material, which has been previously soaked in PRGF, after which PRGF liquid is infiltrated into the sutured area, and the apparently healthy tendon of the proximal and distal stumps (Figure $3 \mathrm{D}$,E) similar to the conservative treatment, and finally infiltrated into the peritendinous regions $[3,42]$. Following the closure of the paratenon and prior to closing the overlying skin, the affected area is covered with a PRGF membrane (Figure 3F). Subsequently, an ultrasound examination of the Achilles tendon is performed during the third week of recovery, the result of which might indicate PRGF infiltration. This proposed surgical treatment was initially implemented by Sanchez and colleagues in 2007 [3], who conducted a case-control study on athletes. They reported a faster recovery of motion, quicker resumption of sport activities, and a smaller increase in tendon cross-sectional area in contrast to a standard repair procedure after 18 months, a data compatible with a reduced fibrotic process in the PRGF group [3]. Other groups confirmed the histological and biomechanical beneficial effects of this procedure in both animals and humans [8,40]. Achieving a shorter immobilization time enables physiotherapy to be sped up due to the formation of a more efficient repair tissue. Therefore, for both the conservative and surgical treatment of Achilles tendon ruptures, early mechanotherapy and physiotherapy are of the utmost importance, and several studies revealed a synergistic effect between PRGF injections and early mechanical stimulation [3,47].

\section{Pitfalls in the Application of PRP for the Repair of Achilles Tendon Ruptures}

The weakest points in demonstrating the consistent effectiveness of PRP primarily reside in the myriad PRP preparation methods, in conjunction with poor standardization in the modalities of their application. These elements somehow hamper advancement and can lead to misleading conclusions regarding their therapeutic efficacy [12,16-18].

\subsection{Whole Blood, Platelet-Rich Plasma, or Platelets Only?}

Whole blood and PRP injections are used to treat Achilles tendon ruptures and tendinopathies with mixed clinical outcomes, which should be of no surprise due to both the different biological composition of PRP and the varied application modalities (Table 1) [3,6,8,10-14,38,48-54]. As an example of this heterogeneity regarding PRPs, Fitzpatrick et al. [55] conducted a meta-analysis of the effectiveness of PRP in the treatment of tendinopathies, which included heterogeneous blood-derived products from seven studies that used autologous whole blood, 11 studies that used leukocyte-rich PRP (LRPRP), one study that used autologous conditioned serum, and one study that applied leukocyte-poor PRP (LP-PRP). PRP products are derived from widely varied methods of preparation [18] that generate a plasma fraction whose only common denominator is a platelet concentration that is superior to peripheral blood. 
Table 1. Summary of studies on human Achilles tendon rupture treatment assisted with platelet-rich plasma.

\begin{tabular}{|c|c|c|c|c|}
\hline Study & Features of the Study & PRP Characteristics & Modality of Application & Outcome \\
\hline Sanchez et al. [3] & $\begin{array}{l}\text { Retrospective case-control } \\
\text { PRGF and surgery } n=6 \\
\text { Control } n=6 \text { only surgery }\end{array}$ & $\begin{array}{l}\text { Citrate as anticoagulant } \\
\text { Activation with } \mathrm{CaCl}_{2} \\
\text { Leukocyte- and erythrocyte-free } \\
\text { Platelets } 2-3 \times\end{array}$ & $\begin{array}{l}\text { Injection of } 4 \mathrm{~mL} \text { of PRGF into the } \\
\text { suture and surrounding areas. } \\
\text { A PRGF membrane to cover the } \\
\text { rupture and sutured area }\end{array}$ & $\begin{array}{l}\text { Faster recovery of motion, quicker return to sporting } \\
\text { activities, and a smaller increase in cross-sectional area on } \\
\text { tendons treated with PRGF after } 18 \text { months }\end{array}$ \\
\hline Sanchez et al. [56] & $\begin{array}{l}\text { Case study } \\
n=2 \\
\text { Surgical repair }\end{array}$ & $\begin{array}{l}\text { Citrate as anticoagulant } \\
\text { Activation with } \mathrm{CaCl}_{2} \\
\text { Leukocyte-and erythrocyte-free } \\
\text { Platelets } 2-3 \times\end{array}$ & $\begin{array}{l}\text { Infiltration of } 3 \mathrm{~mL} \text { of PRGF into each } \\
\text { tendon stump. } \\
\text { A PRGF membrane covering the } \\
\text { affected areas }\end{array}$ & $\begin{array}{l}\text { Successful PRGF-assisted management and recovery of major } \\
\text { post-operative Achilles tendon infection and necrosis after } \\
\text { primary surgical repair. }\end{array}$ \\
\hline Alsousou et al. [9] & $\begin{array}{l}\text { Conservative treatment } \\
\text { Immunohistochemical study } \\
\operatorname{PRP} n=10\end{array}$ & Unreported PRP system & Locally applied PRP. & $\begin{array}{l}\text { PRP promotes better Collagen I deposition, decreased } \\
\text { cellularity, less vascularity, and higher glycosaminoglycans } \\
\text { (GAGs) content compared with the control. }\end{array}$ \\
\hline Keene et al. [12] & $\begin{array}{l}\text { Randomized placebo-controlled trial } \\
\text { PRP } 113 n=10 \\
\text { Control } n=116 \\
\text { Conservative treatment }\end{array}$ & $\begin{array}{l}\text { Leukocyte-rich (LR) PRP } \\
\text { No activation } \\
\text { Not ultrasound-guided (US)-guided } \\
\text { WBC } 2.2 \times \\
\text { Erythrocytes } \\
\text { Platelets } 4.1 \times\end{array}$ & $\begin{array}{l}\text { Local anesthetic injection, then single } \\
\text { percutaneous non-US-guided injection } \\
\text { of } 4 \mathrm{~mL} \text { PRP into the center of the } \\
\text { tendon gap }\end{array}$ & $\begin{array}{l}\text { No functional or clinical benefit in terms of muscle tendon } \\
\text { maximum work, limb symmetry index, heel rise endurance } \\
\text { test, pain, and adverse effects of PRP injection compared with } \\
\text { the placebo. }\end{array}$ \\
\hline De Carli et al. [11] & $\begin{array}{l}\text { Case series } \\
\text { PRP and surgery } n=15 \\
\text { Control, surgery only } n=15\end{array}$ & $\begin{array}{l}\text { Leukocyte-poor (LP) PRP } \\
\text { Liquid PRP, no activation } \\
\text { Gel PRP, activation with thrombin and } \\
\text { Ca-gluconate } \\
\text { Platelets 2-3× }\end{array}$ & $\begin{array}{l}\text { Addition of } 2 \mathrm{~mL} \text { of liquid PRP near } \\
\text { the sutured tendon } \\
2 \mathrm{~mL} \text { of gelatinized PRP sutured to } \\
\text { paratenon. } \\
\text { A second injection of } 4 \mathrm{~mL} \text { of PRP } 14 \\
\text { days post-operatively }\end{array}$ & $\begin{array}{l}\text { The addition of PRP to the surgery did not offer superior } \\
\text { clinical and functional outcomes in terms of Visual Analogue } \\
\text { Scale (VAS) and isokinetic ankle plantar and dorsal flexor } \\
\text { range of motion compared with the control at } 6 \text { and } \\
24 \text { months. }\end{array}$ \\
\hline Alviti et al. [10] & $\begin{array}{l}\text { Retrospective comparative study } \\
\text { Platelet-rich fibrin (PRF) } n=11 \\
\text { No PRF } n=9 \\
\text { Healthy } n=8 \\
\text { Surgical repair }\end{array}$ & $\begin{array}{l}\text { LR-PRP } \\
\text { Activation with batroxobin and Ca-gluconate } \\
\text { to generate a membrane }\end{array}$ & $\begin{array}{l}\text { Application of fibrin glue over the } \\
\text { sutured site }\end{array}$ & $\begin{array}{l}\text { Almost complete restoration of the biomechanics of the gait at } \\
6 \text { months independently of the use of PRF or not. The PRF } \\
\text { group showed significant improvement in efficacy of motion }\end{array}$ \\
\hline
\end{tabular}


Table 1. Cont.

\begin{tabular}{|c|c|c|c|c|}
\hline Study & Features of the Study & PRP Characteristics & Modality of Application & Outcome \\
\hline Zou et al. [13] & $\begin{array}{l}\text { Prospective randomized trial } \\
\text { PRP } n=16 \\
\text { Control } n=20 \\
\text { Surgical repair }\end{array}$ & $\begin{array}{l}\text { LR-PRP } \\
\text { WBC } 4 \times \\
\text { Platelets } 6 \times\end{array}$ & $\begin{array}{l}\text { Injection of PRP into the paratenon } \\
\text { sheath and the surrounding } \\
\text { lacerated tissue }\end{array}$ & $\begin{array}{l}\text { PRP group showed significant short and midterm } \\
\text { improvement in the ankle range of motion, pain, stiffness, } \\
\text { and subjective scores (Leppilahti). } \\
\text { At } 2 \text { years of follow-up, there were no differences between the } \\
\text { PRP and control group for these parameters. }\end{array}$ \\
\hline Arriaza at et al. [8] & $\begin{array}{l}\text { Case series } \\
n=8 \\
\text { Surgical reconstruction }\end{array}$ & $\begin{array}{l}\text { Citrate as anticoagulant } \\
\text { Activation with } \mathrm{CaCl}_{2} \\
\text { Leukocyte-and erythrocyte-free } \\
\text { Platelets } 2-3 \times\end{array}$ & $\begin{array}{l}\text { PRGF injections into the quadriceps } \\
\text { autograft as well as into the } \\
\text { tendon stumps }\end{array}$ & $\begin{array}{l}\text { Successful repair of neglected chronic Achilles tears with } \\
\text { significant improvement in AOFAS score and Boyden } \\
\text { functional score after } 2 \text { years of follow-up. }\end{array}$ \\
\hline Kaniki et al. [15] & $\begin{array}{l}\text { Retrospective comparative study } \\
\text { PRP } n=73 \\
\text { Control } n=72 \\
\text { Conservative treatment }\end{array}$ & $\begin{array}{l}\text { LP-PRP } \\
\text { No activation } \\
\text { Lidocaine as anesthetic } \\
\text { Not US-guided } \\
\text { Platelets } 2-3 \times\end{array}$ & $\begin{array}{l}\text { One injection of } 3-4 \mathrm{~mL} \text { of PRP into the } \\
\text { deep gap that was repeated } 2 \text { weeks } \\
\text { afterwards with the same protocol }\end{array}$ & $\begin{array}{l}\text { No measurable benefit of the addition of PRP to the } \\
\text { conservative treatment in terms of strength or range of } \\
\text { motion of the ankle. }\end{array}$ \\
\hline Boesen et al. [57] & $\begin{array}{l}\text { Randomized double-blinded } \\
\text { prospective study } \\
\text { PRP }=19 \\
\text { Placebo }=19 \\
\text { Conservative treatment }\end{array}$ & $\begin{array}{l}\text { LP-PRP } \\
\text { No activation } \\
\text { US-guided } \\
\text { Platelets } 2-3 \times \\
\text { (2.5× in one sample) }\end{array}$ & $\begin{array}{l}\text { One injection of PRP }(4 \mathrm{~mL}) \text { into the } \\
\text { rupture gap that was repeated every } 2 \\
\text { weeks to complete a total of } \\
\text { four injections }\end{array}$ & $\begin{array}{l}\text { No differences between placebo and PRP groups in term of } \\
\text { clinical benefits assessed by ATRS score or functional } \\
\text { outcomes at any point of follow-up }(2,3,4.5,6,9, \\
\text { and } 12 \text { months) }\end{array}$ \\
\hline
\end{tabular}


Furthermore, these methods eliminate, reduce, or concentrate white blood cells and erythrocytes in different proportions. These two factors will strongly impinge on the biological composition and therapeutic effectiveness of PRP from system to system [18,34,58].

In a randomized single-blinded study conducted on 30 patients who underwent the surgical repair of Achilles tendon rupture assisted by $10 \mathrm{~mL}$ of PRP injected into the rupture site, Schepull et al. [14] did not observe any biomechanical benefit assessed by elasticity modulus in Achilles tendon healing following rupture. However, Schepull et al. applied a platelet concentrate whose platelet concentration was about 17 times higher than the patient's peripheral blood only into the rupture site [14]. The presence of plasma within PRP plays a critical role, since it conveys plasma GFs (HGF, IGF-1, FXII, and complement proteins, among others) and fibrin(ogen), whose absence renders the PRP procedure a bolus delivery system of only some growth factors. This may well prevent the penetration of GFs into tissues, as well as their spatial localization and delivery to the vicinity of cells; thus, exposing GFs to rapid proteolysis (Figure 2) [17,20,21,27].

Recently, Alviti et al. [10] conducted a retrospective trial of patients with acute Achilles tendon rupture who were surgically treated with or without LR-PRP matrices applied over the suture site, and reported an almost complete restoration of the biomechanics of the gait at 6 months in both groups. However, they found that the group of patients treated with PRP augmentation resulted in significant functional improvements in terms of ankle motion efficiency.

On the other hand, Keene et al. [12] conducted a multi-center randomized placebocontrolled trial that involved 113 patients with acute Achilles tendon rupture who were treated with a single percutaneous injection of $4 \mathrm{~mL}$ of LR-PRP into the center of the tendon gap following a previous injection of 1-2 mL local anesthetic into the skin area, avoiding anesthetics into the tendon itself (Figure 3B). The authors stated that the encouraging findings in laboratory studies with PRP did not translate into a detectable patient benefit in tendon injury healing, despite the laboratory studies not recommending the use of leukocyte PRP for the healing of injured tendons $[12,34]$. These and other results (Table 1) contrast with those obtained by Sanchez et al. [3] (the surgical treatment proposal in Figure 3D-F) and Arriaza et al. [8], which ultimately fueled the lingering controversy surrounding whether the inclusion of leukocytes (and erythrocytes) as key ingredients is required to achieve perfect clinical and structural outcomes in tendon repair and application protocols. In this respect, the majority of experimental research suggests that white blood cells (WBCs) exert catabolic and pro-inflammatory effects on tenocytes $[28,34-36,59,60]$. However, the clinical outcomes of PRP injections in tendinopathies are more heterogeneous, with some trials showing beneficial effects of LR-PRP injections compared with saline, corticoid, or control treatments $[48,49,51,52,61]$, whereas other studies reporting no beneficial effects of LR-PRP or whole blood [6,12,38,50,53,54,62-65]. These conflicting results might be partially explained by the heterogeneity of tendinopathies; the anticoagulation, activation, administration, and rehabilitation methods; the type of tendon (Achilles, patella, supraspinatus, extensor carpi radialis brevis, and gluteus medius and minimus tendons); the number of injections; and patient age [66]. Moreover, recent data on tendon-derived stromal fibroblasts and macrophages from patients with Achilles tendinopathy, Achilles rupture, and diseased human supraspinatus tendons have suggested that these cells exhibit complex inflammation signatures involving the NF- $\kappa$ B pathway $[5,43]$, which adds another layer of complexity to the pervasive yet incomplete degenerative paradigm of tendinopathies and tendon ruptures. Tendinopathic fibroblasts mount stronger inflammatory responses in vitro than those of healthy hamstring tendon tenocytes when exposed to IL- $1 \beta$ and IFN $\gamma[5,43]$; a fact associated with altered responsiveness of NF-кB [5,67]. Conceptualized as "stromal fibroblast memory" by Dakin [5,67], this new paradigm might partially account for the lack of improvement in pain and other clinical and functional outcomes of LR-PRP on ruptured and tendinopathic Achilles tendon, rotator cuff tendinopathies and tears, or even knee osteoarthritis, compared with placebo or saline treatments. This is likely to be partially derived from 
the pro-inflammatory and catabolic-induced effects of leukocytes on inflamed stromal cells $[6,12,43,50,54,63-65,68]$. Accordingly, injected leukocytes may induce the release of pro-inflammatory cytokines from primed stromal fibroblasts, which together with the detrimental effects of erythrocyte-derived heme-iron through pro-inflammatory macrophage polarization $[44,58,68,69]$, may operate as non-resolving inflammation and profibrotic agents, respectively $[5,7,67,68]$, even exacerbating the inflammation-driven tendinopathy $[64,65]$. In support of this, studies on tendinopathic fibroblasts, osteoarthritis synoviocytes, and tendon stem cells cultured in leukocyte-containing PRP supernatant have been reported to release significantly higher levels of several pro-inflammatory cytokines compared with leukocyte-depleted PRP [34-36], similar to PRP with leukocytes that simulate the inflammatory conditions with lipopolysaccharides (LPS) and whose supernatant releases significantly higher amounts of pro-inflammatory cytokines compared with the supernatant of LP-PRP [59]. Finally, platelets are an important source of Lipoxin A4 (LXA 4 , an endogenous arachidonic acid-derived pro-resolving mediator that has been reported to counter-regulate inflammatory processes in cells from patients with Achilles ruptures and Achilles tendinopathies [67].

\subsection{PRP Application Modalities}

Another important factor in the therapeutic application outcomes of PRP relates to the protocols utilized for its administration [17]. In a study by Keene et al. [12], the only percutaneous injection of non-activated PRP was infiltrated into the center of the Achilles tendon gap. Similarly, Schepull et al. [14] only applied a platelet concentrate into the rupture site following suturing. Alviti et al. [10] applied a platelet-rich fibrin (PRF) membrane but did not infiltrate the tendon stumps, yet significant functional improvements resulted in terms of the efficiency of ankle motion, contrary to Zou et al. [13], who injected into the tendon stumps but did not place a membrane, yet found biomechanical improvement over the short and midterm compared with a control group, but not at 2 years of follow-up (Table 1). On the other hand, Arriaza et al. [8] treated eight patients with chronic Achilles tears using a quadriceps tendon autograft, which was infiltrated with plasma rich in growth factors (PRGF), as well as the Achilles tendon stumps, and reported excellent clinical and functional scores.

Tendon rupture sites present a gap that is usually occupied by a hematoma and necrotic tendon (Figure 3A) tissue that, in Achilles tendon ruptures treated surgically, are evacuated and debrided, respectively [42]. The ruptured areas are a source of inflammatory mediators which stem primarily from blood-derived neutrophils and monocytes, tissue-resident macrophages, erythrocyte-derived heme iron, and dying tenocytes [68]. In this context, PRP injected into the ruptured gap might exert anti-inflammatory, immunomodulatory, anti-apoptotic, and anti-fibrotic effects, provided that the PRP composition is leukocyte- and erythrocyte-free [3,34]. However, we suggest that to promote the functional and structural healing process of a ruptured tendon it is not enough to simply infiltrate PRP into the tendon gap. Further to the immunocompetent cells that reside in a healthy and dysregulated tissues next to the damaged region [43], another important target for the GFs and cytokines of PRP are the healthy tendon-residing stem cells and their niches, at both the healthy proximal and distal stumps of the ruptured tendon $[3,70]$. These should also be injected to stimulate tendon regrowth toward partially bridging the tendon gap (Figure 3C-E) [3]. Even in the best-case scenario, the function of the tendon-muscle unit would be biomechanically compromised due to the elongation generated by the newly formed tissue that bridges the tendon gap. Only by hypothesizing that tendon repair would be specifically driven through the adaptive cellular reprogramming of adult differentiated cells like tenocytes that survive within the hypoxic and necrotic tissue-injured microenvironment would the tendon heal through this single injection approach and therefore achieve the therapeutic purpose. There are several examples of this cell plasticity in tissue repair and regeneration including fibroblast/myofibroblast differentiation, Myelin/Remak Schwann cells repairing (Bungner) Schwann cell trans-differentiation, and macrophage 
(M1, M2, M3, M4) and neutrophil polarization [71,72], to which PRP might contribute as well [45,73-75].

\subsection{PRP Activation and $p H$}

Whereas ex vivo PRP activation with $\mathrm{CaCl}_{2}$ gives rise to a gradual liquid-to-gel dynamic scaffold and a functionalized fibrin matrix, which circumvents the short half-life and the rapid GF proteolytic degradation [17,19], the direct injection of non-activated PRP [11,12] conveys platelets that might interact with the injured tissue microenvironment. Whereas some platelets will be activated by tissue collagen-von Willebrand factor complexes, thrombin, and platelet-derived thromboxane $\mathrm{A}_{2}$ within the injured tissue [76] and release their cargo in a bolus manner, other platelets might adhere to monocytes and, through the nuclear translocation of NF- $\mathrm{KB}$, induce the expression of NF- $\mathrm{kB}$-dependent inflammatory genes on monocytes. In doing so, monocytes generate pro-inflammatory cytokines [77]. Furthermore, when directly injected non-activated PRP, platelets might activate the complement system and promote the formation of platelet-leukocyte complexes and neutrophil extracellular traps (NETs) in situ. This may exacerbate the already inflamed microenvironment, which may be amplified by the leukocytes of LR-PRP, as stated above $[68,77]$. On the other hand, there are doubts as to whether the in vitro determination of growth factors following the freezing of platelets and lysing them with Triton-X-100 [12] might correspond to growth factors released in vivo following contact with tendon collagen. Perhaps an in vitro activation with collagen would be more representative, since platelets respond differently to distinct types of stimulus. The additional activation of PRP with thrombin appears to be unnecessary, as $\mathrm{CaCl}_{2}$ adds calcium (Factor IV of the coagulation cascade), which restores extracellular matrix (ECM) calcium homeostasis and generates a low yet efficient amount of autologous thrombin [76], thereby yielding a gradual and dynamic liquid-to gel scaffold injectable within a roughly 1-5 min window, during which PRP is macroscopically manageable as a liquid, or a fibrin membrane 20 min following activation $[3,17,19,23,42]$. However, whereas low concentrations of thrombin exhibit growth factor-like fibroblast and endothelial cell proliferation migration, antiapoptotic, and inflammatory modulation activities, high doses of thrombin would operate as an inflammatory mediator that recruits monocytes, activates the NF- $\mathrm{kB}$ of endothelial cells, and triggers the release of cytokines from mast cells [24,76]. Moreover, exogenous activation with commercially available thrombin (bovine) might be associated with adverse effects, which include immune reactions, thrombosis, and hemorrhages [78].

Another area of concern relates to the $\mathrm{pH}$ of PRP, where PRP preparation devices and studies should provide its precise characterization, which should also include the $\mathrm{pH}$ of the product that is ready to be injected, among many other parameters that convey its biological properties $[18,35]$. In some studies, based on the acidic properties of acid citrate dextrose (ACD), which is used as anticoagulant, a basic buffer solution of $8.4 \%$ sodium bicarbonate was added to adjust an unknown PRP $\mathrm{pH}$ to physiologic $\mathrm{pH}$ prior to injection to address Achilles or tennis elbow tendinopathy $[38,53,54,79]$. As examples, the excellently designed and carefully conducted trials by Krogh et al. [53,54], who, through the use of an ultrasoundguided single percutaneous injection of LR-PRP into the elbow lateral common tendon and Achilles tendon, respectively, did not observe any clinical or functional improvement compared with a saline or glucocorticoid group. It is worthy of note that the acidity of plasma is contingent on the quantity of citrate used [79]. Some PRP devices may or may not use ACD as an anticoagulant (PRP pH values of 7.0 and 8.0 respectively) and, due to its acidic $\mathrm{pH}(\mathrm{ACD}$ presents a $\mathrm{pH}=4.98$ [35]), device manufacturers recommend the use of $8.4 \%$ sodium bicarbonate in the former procedure (Biomet GPS III, Biomet Biologics). Similarly, the $\mathrm{pH}$ values of other commercial PRP kits using ACD ranged from 6.59 (SmartPrep2, Terumo Harvest) to 7.05 (GPS III, Biomet Biologics) in the measures reported by Fitzpatrick et al. [80]. Accordingly, in a technical analysis of PRP applied to treat tendinopathies, Kaux et al. [81] reported that in the majority of studies that used $\mathrm{ACD}$ as an anticoagulant, researchers added a buffer solution. However, other devices that 
also use citrate (trisodium citrate) [79] present a $\mathrm{pH}$ of $7.64 \pm 0.09$ prior to activation and $7.53 \pm 0.09$ once it has been activated with $10 \% \mathrm{CaCl}_{2}$ [82]. These $\mathrm{pH}$ values are far different from the acidic $\mathrm{pH}$ values reported by some studies and are attributed to $\mathrm{CaCl}_{2}(\mathrm{pH}$ of 6.3) [18,78], which makes the addition of a buffer solution unnecessary in this case [82]. Importantly, the associated administration of local anesthetics (bupivacaine and lidocaine) and corticoids (methylprednisolone) with PRP should be avoided, since it has been reported that these drugs decrease the viability and proliferation of tenocytes $[38,83,84]$.

\section{Future Perspectives}

Selecting the right biological scaffold and applying it correctly to restitutio ad integrum of ruptured Achilles tendons remains a daunting and complex task. Although PRP has many characteristics that make it an attractive treatment, its application is still nascent. The scientific community continues to learn and garner valuable insights to enhance the potential of PRP treatment via intellectual, technological, and research efforts into some of the biological and practical bottlenecks. Prior use and research of PRP has failed to fully address issues to optimize structural and functional PRP-mediated tendon repair outcomes; therefore, the clinical use of and research into PRP in the treatment of Achilles tendon tears has now been limited to its use as adjunctive treatment with surgery. The advances that emerge from synergies between natural and synthetic biology will lead to the generation of optimal biological scaffolds and guide their best possible application in the treatment of Achilles tendons in conjunction with functional rehabilitation.

Author Contributions: Conceptualization: S.P., E.A., M.S., J.T., and R.C.; methodology: S.P., E.A., R.P., F.B., and G.S.; writing —original draft: S.P. and E.A.; writing—review and editing: S.P., E.A, M.S., J.T., R.P., F.B., G.A.M., C.J.R., S.S., R.E., R.C., V.V., N.F., J.A., G.S., and R.S. All authors have read and agreed to the published version of the manuscript.

Funding: This research received no external funding.

Institutional Review Board Statement: Not applicable.

Informed Consent Statement: Not applicable.

Data Availability Statement: Not applicable.

Conflicts of Interest: The authors declare that E.A. is the Scientific Director of and S.P. and R.P. are scientists at BTI Biotechnology Institute, a biomedical company that investigates in the fields of regenerative medicine and PRGF-Endoret technology. The rest of the authors state that that they have no conflicts of interest that are relevant to the content of this article.

\section{References}

1. Park, S.H.; Lee, H.S.; Young, K.W.; Seo, S.G. Treatment of Acute Achilles Tendon Rupture. Clin. Orthop. Surg. 2020, 12, 1-8. [CrossRef] [PubMed]

2. Sanchez, M.; Anitua, E.; Orive, G.; Mujika, I.; Andia, I. Platelet-rich therapies in the treatment of orthopaedic sport injuries. Sports Med. 2009, 39, 345-354. [CrossRef] [PubMed]

3. Sanchez, M.; Anitua, E.; Azofra, J.; Andia, I.; Padilla, S.; Mujika, I. Comparison of surgically repaired Achilles tendon tears using platelet-rich fibrin matrices. Am. J. Sports Med. 2007, 35, 245-251. [CrossRef] [PubMed]

4. Millar, N.L.; Murrell, G.A.C.; McInnes, I.B. Inflammatory mechanisms in tendinopathy-Towards translation. Nat. Rev. Rheumatol. 2017, 13, 110-122. [CrossRef] [PubMed]

5. Dakin, S.G.; Buckley, C.D.; Al-Mossawi, M.H.; Hedley, R.; Martinez, F.O.; Wheway, K.; Watkins, B.; Carr, A.J. Persistent stromal fibroblast activation is present in chronic tendinopathy. Arthritis Res. Ther. 2017, 19, 16. [CrossRef]

6. Carr, A.J.; Murphy, R.; Dakin, S.G.; Rombach, I.; Wheway, K.; Watkins, B.; Franklin, S.L. Platelet-Rich Plasma Injection with Arthroscopic Acromioplasty for Chronic Rotator Cuff Tendinopathy: A Randomized Controlled Trial. Am. J. Sports Med. 2015, 43, 2891-2897. [CrossRef]

7. Rees, J.D.; Stride, M.; Scott, A. Tendons-Time to revisit inflammation. Br. J. Sports Med. 2014, 48, 1553-1557. [CrossRef]

8. Arriaza, R.; Arriaza, A.; Lopez-Vidriero, E.; Gayoso, R.; Agrasar, C.; Saavedra-Garcia, M.A. Quadriceps tendon autograft and platelet rich plasma injection to treat chronic Achilles tears-a minimum two-year follow-up. Ann. Transl. Med. 2019, 7, 746. [CrossRef]

9. Alsousou, J.; Thompson, M.; Harrison, P.; Willett, K.; Franklin, S. Effect of platelet-rich plasma on healing tissues in acute ruptured Achilles tendon: A human immunohistochemistry study. Lancet 2015, 385 (Suppl. 1), S19. [CrossRef] 
10. Alviti, F.; Gurzi, M.; Santilli, V.; Paoloni, M.; Padua, R.; Bernetti, A.; Bernardi, M.; Mangone, M. Achilles Tendon Open Surgical Treatment with Platelet-Rich Fibrin Matrix Augmentation: Biomechanical Evaluation. J. Foot Ankle Surg. 2017, 56, 581-585. [CrossRef]

11. De Carli, A.; Lanzetti, R.M.; Ciompi, A.; Lupariello, D.; Vadala, A.; Argento, G.; Ferretti, A.; Vulpiani, M.C.; Vetrano, M. Can platelet-rich plasma have a role in Achilles tendon surgical repair? Knee Surg. Sports Traumatol. Arthrosc. 2016, 24, $2231-2237$. [CrossRef] [PubMed]

12. Keene, D.J.; Alsousou, J.; Harrison, P.; Hulley, P.; Wagland, S.; Parsons, S.R.; Thompson, J.Y.; O'Connor, H.M.; Schlussel, M.M.; Dutton, S.J.; et al. Platelet rich plasma injection for acute Achilles tendon rupture: PATH-2 randomised, placebo controlled, superiority trial. BMJ 2019, 367, 16132. [CrossRef] [PubMed]

13. Zou, J.; Mo, X.; Shi, Z.; Li, T.; Xue, J.; Mei, G.; Li, X. A Prospective Study of Platelet-Rich Plasma as Biological Augmentation for Acute Achilles Tendon Rupture Repair. BioMed Res. Int. 2016, 2016, 9364170. [CrossRef] [PubMed]

14. Schepull, T.; Kvist, J.; Norrman, H.; Trinks, M.; Berlin, G.; Aspenberg, P. Autologous platelets have no effect on the healing of human achilles tendon ruptures: A randomized single-blind study. Am. J. Sports Med. 2011, 39, 38-47. [CrossRef] [PubMed]

15. Kaniki, N.; Willits, K.; Mohtadi, N.G.; Fung, V.; Bryant, D. A retrospective comparative study with historical control to determine the effectiveness of platelet-rich plasma as part of nonoperative treatment of acute achilles tendon rupture. Arthroscopy 2014, 30, 1139-1145. [CrossRef]

16. Nourissat, G.; Ornetti, P.; Berenbaum, F.; Sellam, J.; Richette, P.; Chevalier, X. Does platelet-rich plasma deserve a role in the treatment of tendinopathy? Jt. Bone Spine 2015, 82, 230-234. [CrossRef]

17. Anitua, E.; Nurden, P.; Prado, R.; Nurden, A.T.; Padilla, S. Autologous fibrin scaffolds: When platelet- and plasma-derived biomolecules meet fibrin. Biomaterials 2019, 192, 440-460. [CrossRef]

18. DeLong, J.M.; Russell, R.P.; Mazzocca, A.D. Platelet-rich plasma: The PAW classification system. Arthroscopy 2012, 28, 998-1009. [CrossRef]

19. Anitua, E. Plasma rich in growth factors: Preliminary results of use in the preparation of future sites for implants. Int. J. Oral Maxillofac. Implants 1999, 14, 529-535.

20. Sarrazin, S.; Lamanna, W.C.; Esko, J.D. Heparan sulfate proteoglycans. Cold Spring Harb. Perspect. Biol. 2011, 3, a004952. [CrossRef]

21. Martino, M.M.; Briquez, P.S.; Guc, E.; Tortelli, F.; Kilarski, W.W.; Metzger, S.; Rice, J.J.; Kuhn, G.A.; Muller, R.; Swartz, M.A.; et al. Growth factors engineered for super-affinity to the extracellular matrix enhance tissue healing. Science 2014, 343, 885-888. [CrossRef] [PubMed]

22. Mitchell, A.C.; Briquez, P.S.; Hubbell, J.A.; Cochran, J.R. Engineering growth factors for regenerative medicine applications. Acta Biomater. 2016, 30, 1-12. [CrossRef] [PubMed]

23. Anitua, E.; Prado, R.; Azkargorta, M.; Rodriguez-Suarez, E.; Iloro, I.; Casado-Vela, J.; Elortza, F.; Orive, G. High-throughput proteomic characterization of plasma rich in growth factors (PRGF-Endoret)-derived fibrin clot interactome. J. Tissue Eng. Regen. Med. 2015, 9, E1-E12. [CrossRef] [PubMed]

24. Strukova, S. Blood coagulation-dependent inflammation. Coagulation-dependent inflammation and inflammation-dependent thrombosis. Front. Biosci. 2006, 11, 59-80. [CrossRef]

25. Briquez, P.S.; Hubbell, J.A.; Martino, M.M. Extracellular Matrix-Inspired Growth Factor Delivery Systems for Skin Wound Healing. Adv. Wound Care 2015, 4, 479-489. [CrossRef]

26. Neuss, S.; Schneider, R.K.; Tietze, L.; Knüchel, R.; Jahnen-Dechent, W. Secretion of fibrinolytic enzymes facilitates human mesenchymal stem cell invasion into fibrin clots. Cells Tissues Organs 2010, 191, 36-46. [CrossRef]

27. Sacchi, V.; Mittermayr, R.; Hartinger, J.; Martino, M.M.; Lorentz, K.M.; Wolbank, S.; Hofmann, A.; Largo, R.A.; Marschall, J.S.; Groppa, E.; et al. Long-lasting fibrin matrices ensure stable and functional angiogenesis by highly tunable, sustained delivery of recombinant VEGF164. Proc. Natl. Acad. Sci. USA 2014, 111, 6952-6957. [CrossRef]

28. Anitua, E.; Zalduendo, M.M.; Prado, R.; Alkhraisat, M.H.; Orive, G. Morphogen and proinflammatory cytokine release kinetics from PRGF-Endoret fibrin scaffolds: Evaluation of the effect of leukocyte inclusion. J. Biomed. Mater. Res. A 2015, 103, 1011-1020. [CrossRef]

29. Janmey, P.A.; Miller, R.T. Mechanisms of mechanical signaling in development and disease. J. Cell Sci. 2011, 124, 9-18. [CrossRef]

30. Anitua, E.; Sanchez, M.; Nurden, A.T.; Zalduendo, M.; de la Fuente, M.; Orive, G.; Azofra, J.; Andia, I. Autologous fibrin matrices: A potential source of biological mediators that modulate tendon cell activities. J. Biomed. Mater. Res. A 2006, 77, 285-293. [CrossRef]

31. Sanchez, M.; Anitua, E.; Azofra, J.; Prado, R.; Muruzabal, F.; Andia, I. Ligamentization of tendon grafts treated with an endogenous preparation rich in growth factors: Gross morphology and histology. Arthroscopy 2010, 26, 470-480. [CrossRef] [PubMed]

32. Jo, C.H.; Kim, J.E.; Yoon, K.S.; Shin, S. Platelet-rich plasma stimulates cell proliferation and enhances matrix gene expression and synthesis in tenocytes from human rotator cuff tendons with degenerative tears. Am. J. Sports Med. 2012, 40, 1035-1045. [CrossRef] [PubMed]

33. Chen, L.; Liu, J.P.; Tang, K.L.; Wang, Q.; Wang, G.D.; Cai, X.H.; Liu, X.M. Tendon derived stem cells promote platelet-rich plasma healing in collagenase-induced rat achilles tendinopathy. Cell. Physiol. Biochem. 2014, 34, 2153-2168. [CrossRef] [PubMed]

34. Zhou, Y.; Zhang, J.; Wu, H.; Hogan, M.V.; Wang, J.H. The differential effects of leukocyte-containing and pure platelet-rich plasma (PRP) on tendon stem/progenitor cells-Implications of PRP application for the clinical treatment of tendon injuries. Stem Cell. Res. Ther. 2015, 6, 173. [CrossRef] [PubMed] 
35. Cross, J.A.; Cole, B.J.; Spatny, K.P.; Sundman, E.; Romeo, A.A.; Nicholson, G.P.; Wagner, B.; Fortier, L.A. Leukocyte-Reduced Platelet-Rich Plasma Normalizes Matrix Metabolism in Torn Human Rotator Cuff Tendons. Am. J. Sports Med. 2015, 43, 2898-2906. [CrossRef] [PubMed]

36. Yan, R.; Gu, Y.; Ran, J.; Hu, Y.; Zheng, Z.; Zeng, M.; Heng, B.C.; Chen, X.; Yin, Z.; Chen, W.; et al. Intratendon Delivery of Leukocyte-Poor Platelet-Rich Plasma Improves Healing Compared With Leukocyte-Rich Platelet-Rich Plasma in a Rabbit Achilles Tendinopathy Model. Am. J. Sports Med. 2017, 45, 1909-1920. [CrossRef]

37. De Almeida, A.M.; Demange, M.K.; Sobrado, M.F.; Rodrigues, M.B.; Pedrinelli, A.; Hernandez, A.J. Patellar tendon healing with platelet-rich plasma: A prospective randomized controlled trial. Am. J. Sports Med. 2012, 40, 1282-1288. [CrossRef]

38. Gosens, T.; Den Oudsten, B.L.; Fievez, E.; van't Spijker, P.; Fievez, A. Pain and activity levels before and after platelet-rich plasma injection treatment of patellar tendinopathy: A prospective cohort study and the influence of previous treatments. Int. Orthop. 2012, 36, 1941-1946. [CrossRef]

39. Aspenberg, P.; Virchenko, O. Platelet concentrate injection improves Achilles tendon repair in rats. Acta Orthop. Scand. 2004, 75, 93-99. [CrossRef]

40. Lopez-Najera, D.; Rubio-Zaragoza, M.; Sopena-Juncosa, J.J.; Alentorn-Geli, E.; Cugat-Bertomeu, R.; Fernandez-Sarmiento, J.A.; Dominguez-Perez, J.M.; Garcia-Balletbo, M.; Primo-Capella, V.J.; Carrillo-Poveda, J.M. Effects of plasma rich in growth factors (PRGF) on biomechanical properties of Achilles tendon repair. Knee Surg. Sports Traumatol. Arthrosc. 2016, 24, 3997-4004. [CrossRef]

41. Borselli, C.; Storrie, H.; Benesch-Lee, F.; Shvartsman, D.; Cezar, C.; Lichtman, J.W.; Vandenburgh, H.H.; Mooney, D.J. Functional muscle regeneration with combined delivery of angiogenesis and myogenesis factors. Proc. Natl. Acad. Sci. USA 2010, 107, 3287-3292. [CrossRef] [PubMed]

42. Sánchez, M.; Delgado, D.; Garate, A.; Sánchez, P.; Oraa, J.; Bilbao, A.M.; Guadilla, J.; Aizpurua, B.; Fiz, N.; Azofra, J.; et al. PRP Injections in Orthopaedic Surgery: Why, When and How to Use PRP Dynamic Liquid Scaffold Injections in Orthopaedic Surgery. In Plasma Medicine—Concepts and Clinical Applications; Tutar, Y., Tutar, L., Eds.; IntechOpen: London, UK, 2018.

43. Dakin, S.G.; Newton, J.; Martinez, F.O.; Hedley, R.; Gwilym, S.; Jones, N.; Reid, H.A.B.; Wood, S.; Wells, G.; Appleton, L.; et al. Chronic inflammation is a feature of Achilles tendinopathy and rupture. Br. J. Sports Med. 2018, 52, 359-367. [CrossRef] [PubMed]

44. Dakin, S.G.; Coles, M.; Sherlock, J.P.; Powrie, F.; Carr, A.J.; Buckley, C.D. Pathogenic stromal cells as therapeutic targets in joint inflammation. Nat. Rev. Rheumatol. 2018, 14, 714-726. [CrossRef] [PubMed]

45. Nishio, H.; Saita, Y.; Kobayashi, Y.; Takaku, T.; Fukusato, S.; Uchino, S.; Wakayama, T.; Ikeda, H.; Kaneko, K. Platelet-rich plasma promotes recruitment of macrophages in the process of tendon healing. Regen. Ther. 2020, 14, 262-270. [CrossRef] [PubMed]

46. Chernysh, I.N.; Weisel, J.W. Dynamic imaging of fibrin network formation correlated with other measures of polymerization. Blood 2008, 111, 4854-4861. [CrossRef] [PubMed]

47. Neph, A.; Schroeder, A.; Enseki, K.R.; Everts, P.A.; Wang, J.H.; Onishi, K. Role of Mechanical Loading for Platelet-Rich PlasmaTreated Achilles Tendinopathy. Curr. Sports Med. Rep. 2020, 19, 209-216. [CrossRef] [PubMed]

48. Fitzpatrick, J.; Bulsara, M.K.; O’Donnell, J.; Zheng, M.H. Leucocyte-Rich Platelet-Rich Plasma Treatment of Gluteus Medius and Minimus Tendinopathy: A Double-Blind Randomized Controlled Trial with 2-Year Follow-up. Am. J. Sports Med. 2019, 47, 1130-1137. [CrossRef]

49. Fitzpatrick, J.; Bulsara, M.K.; O'Donnell, J.; McCrory, P.R.; Zheng, M.H. The Effectiveness of Platelet-Rich Plasma Injections in Gluteal Tendinopathy: A Randomized, Double-Blind Controlled Trial Comparing a Single Platelet-Rich Plasma Injection With a Single Corticosteroid Injection. Am. J. Sports Med. 2018, 46, 933-939. [CrossRef]

50. De Vos, R.J.; Weir, A.; van Schie, H.T.; Bierma-Zeinstra, S.M.; Verhaar, J.A.; Weinans, H.; Tol, J.L. Platelet-rich plasma injection for chronic Achilles tendinopathy: A randomized controlled trial. JAMA 2010, 303, 144-149. [CrossRef]

51. Dragoo, J.L.; Wasterlain, A.S.; Braun, H.J.; Nead, K.T. Platelet-rich plasma as a treatment for patellar tendinopathy: A double-blind, randomized controlled trial. Am. J. Sports Med. 2014, 42, 610-618. [CrossRef]

52. Mishra, A.K.; Skrepnik, N.V.; Edwards, S.G.; Jones, G.L.; Sampson, S.; Vermillion, D.A.; Ramsey, M.L.; Karli, D.C.; Rettig, A.C. Efficacy of platelet-rich plasma for chronic tennis elbow: A double-blind, prospective, multicenter, randomized controlled trial of 230 patients. Am. J. Sports Med. 2014, 42, 463-471. [CrossRef] [PubMed]

53. Krogh, T.P.; Fredberg, U.; Stengaard-Pedersen, K.; Christensen, R.; Jensen, P.; Ellingsen, T. Treatment of lateral epicondylitis with platelet-rich plasma, glucocorticoid, or saline: A randomized, double-blind, placebo-controlled trial. Am. J. Sports Med. 2013, 41, 625-635. [CrossRef] [PubMed]

54. Krogh, T.P.; Ellingsen, T.; Christensen, R.; Jensen, P.; Fredberg, U. Ultrasound-Guided Injection Therapy of Achilles Tendinopathy with Platelet-Rich Plasma or Saline: A Randomized, Blinded, Placebo-Controlled Trial. Am. J. Sports Med. 2016, 44, 1990-1997. [CrossRef] [PubMed]

55. Fitzpatrick, J.; Bulsara, M.; Zheng, M.H. The Effectiveness of Platelet-Rich Plasma in the Treatment of Tendinopathy: A Metaanalysis of Randomized Controlled Clinical Trials. Am. J. Sports Med. 2017, 45, 226-233. [CrossRef] [PubMed]

56. Sánchez, M.; Anitua, E.; Cole, A.; Da Silva, A.; Azofra, J.; Andia, I. Management of post-surgical Achilles tendon complications with a preparation rich in growth factors: A study of two-cases. Inj. Extra 2009, 40, 11-15. [CrossRef]

57. Boesen, A.P.; Boesen, M.I.; Hansen, R.; Barfod, K.W.; Lenskjold, A.; Malliaras, P.; Langberg, H. Effect of Platelet-Rich Plasma on Nonsurgically Treated Acute Achilles Tendon Ruptures: A Randomized, Double-Blinded Prospective Study. Am. J. Sports Med. 2020, 48, 2268-2276. [CrossRef] 
58. Everts, P.A.; Malanga, G.A.; Paul, R.V.; Rothenberg, J.B.; Stephens, N.; Mautner, K.R. Assessing clinical implications and perspectives of the pathophysiological effects of erythrocytes and plasma free hemoglobin in autologous biologics for use in musculoskeletal regenerative medicine therapies. A review. Regen. Ther. 2019, 11, 56-64. [CrossRef]

59. Anitua, E.; Zalduendo, M.; Troya, M.; Padilla, S.; Orive, G. Leukocyte inclusion within a platelet rich plasma-derived fibrin scaffold stimulates a more pro-inflammatory environment and alters fibrin properties. PLoS ONE 2015, 10, e0121713. [CrossRef]

60. Hudgens, J.L.; Sugg, K.B.; Grekin, J.A.; Gumucio, J.P.; Bedi, A.; Mendias, C.L. Platelet-Rich Plasma Activates Proinflammatory Signaling Pathways and Induces Oxidative Stress in Tendon Fibroblasts. Am. J. Sports Med. 2016, 44, 1931-1940. [CrossRef]

61. Gosens, T.; Peerbooms, J.C.; van Laar, W.; den Oudsten, B.L. Ongoing positive effect of platelet-rich plasma versus corticosteroid injection in lateral epicondylitis: A double-blind randomized controlled trial with 2-year follow-up. Am. J. Sports Med. 2011, 39, 1200-1208. [CrossRef]

62. Bell, K.J.; Fulcher, M.L.; Rowlands, D.S.; Kerse, N. Impact of autologous blood injections in treatment of mid-portion Achilles tendinopathy: Double blind randomised controlled trial. BMJ 2013, 346, f2310. [CrossRef]

63. De Vos, R.J.; Weir, A.; Tol, J.L.; Verhaar, J.A.; Weinans, H.; van Schie, H.T. No effects of PRP on ultrasonographic tendon structure and neovascularisation in chronic midportion Achilles tendinopathy. Br. J. Sports Med. 2011, 45, 387-392. [CrossRef]

64. Schwitzguebel, A.J.; Kolo, F.C.; Tirefort, J.; Kourhani, A.; Nowak, A.; Gremeaux, V.; Saffarini, M.; Ladermann, A. Efficacy of Platelet-Rich Plasma for the Treatment of Interstitial Supraspinatus Tears: A Double-Blinded, Randomized Controlled Trial. Am. J. Sports Med. 2019, 47, 1885-1892. [CrossRef]

65. Scott, A.; LaPrade, R.F.; Harmon, K.G.; Filardo, G.; Kon, E.; Della Villa, S.; Bahr, R.; Moksnes, H.; Torgalsen, T.; Lee, J.; et al. Platelet-Rich Plasma for Patellar Tendinopathy: A Randomized Controlled Trial of Leukocyte-Rich PRP or Leukocyte-Poor PRP Versus Saline. Am. J. Sports Med. 2019, 47, 1654-1661. [CrossRef]

66. Abat, F.; Alfredson, H.; Cucchiarini, M.; Madry, H.; Marmotti, A.; Mouton, C.; Oliveira, J.M.; Pereira, H.; Peretti, G.M.; Spang, C.; et al. Current trends in tendinopathy: Consensus of the ESSKA basic science committee. Part II: Treatment options. J. Exp. Orthop. 2018, 5, 38. [CrossRef]

67. Dakin, S.G.; Colas, R.A.; Newton, J.; Gwilym, S.; Jones, N.; Reid, H.A.B.; Wood, S.; Appleton, L.; Wheway, K.; Watkins, B.; et al. 15-Epi-LXA4 and MaR1 counter inflammation in stromal cells from patients with Achilles tendinopathy and rupture. FASEB J. 2019, 33, 8043-8054. [CrossRef] [PubMed]

68. Scott, A.; Khan, K.M.; Roberts, C.R.; Cook, J.L.; Duronio, V. What do we mean by the term "inflammation"? A contemporary basic science update for sports medicine. Br. J. Sports Med. 2004, 38, 372-380. [CrossRef] [PubMed]

69. Soares, M.P.; Hamza, I. Macrophages and Iron Metabolism. Immunity 2016, 44, 492-504. [CrossRef] [PubMed]

70. Zhang, J.; Middleton, K.K.; Fu, F.H.; Im, H.J.; Wang, J.H. HGF mediates the anti-inflammatory effects of PRP on injured tendons. PLoS ONE 2013, 8, e67303. [CrossRef] [PubMed]

71. Mosteiro, L.; Pantoja, C.; Alcazar, N.; Marion, R.M.; Chondronasiou, D.; Rovira, M.; Fernandez-Marcos, P.J.; Munoz-Martin, M.; Blanco-Aparicio, C.; Pastor, J.; et al. Tissue damage and senescence provide critical signals for cellular reprogramming in vivo. Science 2016, 354, aaf4445. [CrossRef]

72. Jessen, K.R.; Mirsky, R. The repair Schwann cell and its function in regenerating nerves. J. Physiol. 2016, 594, 3521-3531. [CrossRef] [PubMed]

73. Anitua, E.; Sanchez, M.; Merayo-Lloves, J.; De la Fuente, M.; Muruzabal, F.; Orive, G. Plasma rich in growth factors (PRGFEndoret) stimulates proliferation and migration of primary keratocytes and conjunctival fibroblasts and inhibits and reverts TGF-beta1-Induced myodifferentiation. Investig. Ophthalmol. Vis. Sci. 2011, 52, 6066-6073. [CrossRef] [PubMed]

74. Renn, T.Y.; Kao, Y.H.; Wang, C.C.; Burnouf, T. Anti-inflammatory effects of platelet biomaterials in a macrophage cellular model. Vox Sang. 2015, 109, 138-147. [CrossRef] [PubMed]

75. Vasina, E.M.; Cauwenberghs, S.; Feijge, M.A.; Heemskerk, J.W.; Weber, C.; Koenen, R.R. Microparticles from apoptotic platelets promote resident macrophage differentiation. Cell Death Dis. 2011, 2, e211. [CrossRef] [PubMed]

76. Estevez, B.; Du, X. New Concepts and Mechanisms of Platelet Activation Signaling. Physiology (Bethesda) 2017, 32, 162-177. [CrossRef]

77. Vieira-de-Abreu, A.; Campbell, R.A.; Weyrich, A.S.; Zimmerman, G.A. Platelets: Versatile effector cells in hemostasis, inflammation, and the immune continuum. Semin. Immunopathol. 2012, 34, 5-30. [CrossRef]

78. Lansdown, D.A.; Fortier, L.A. Platelet-Rich Plasma: Formulations, Preparations, Constituents, and Their Effects. Oper. Tech. Sports Med. 2017, 25, 7-12. [CrossRef]

79. Laffan, M.; Manning, R. Chapter 16-Investigation of haemostasis. In Dacie and Lewis Practical Haematology, 10th ed.; Lewis, S.M., Bain, B.J., Bates, I., Eds.; Churchill Livingstone: Philadelphia, PA, USA, 2006; pp. 379-440.

80. Fitzpatrick, J.; Bulsara, M.K.; McCrory, P.R.; Richardson, M.D.; Zheng, M.H. Analysis of Platelet-Rich Plasma Extraction: Variations in Platelet and Blood Components between 4 Common Commercial Kits. Orthop. J. Sports Med. 2017, 5, 2325967116675272. [CrossRef]

81. Kaux, J.F.; Emonds-Alt, T. The use of platelet-rich plasma to treat chronic tendinopathies: A technical analysis. Platelets 2018, 29, 213-227. [CrossRef]

82. Anitua, E.; de la Fuente, M.; Alcalde, I.; Sanchez, C.; Merayo-Lloves, J.; Muruzabal, F. Development and Optimization of Freeze-Dried Eye Drops Derived from Plasma Rich in Growth Factors Technology. Transl. Vis. Sci. Technol. 2020, 9, 35. [CrossRef] 
83. Beitzel, K.; McCarthy, M.B.; Cote, M.P.; Apostolakos, J.; Russell, R.P.; Bradley, J.; ElAttrache, N.S.; Romeo, A.A.; Arciero, R.A.; Mazzocca, A.D. The effect of ketorolac tromethamine, methylprednisolone, and platelet-rich plasma on human chondrocyte and tenocyte viability. Arthroscopy 2013, 29, 1164-1174. [CrossRef] [PubMed]

84. Carofino, B.; Chowaniec, D.M.; McCarthy, M.B.; Bradley, J.P.; Delaronde, S.; Beitzel, K.; Cote, M.P.; Arciero, R.A.; Mazzocca, A.D. Corticosteroids and local anesthetics decrease positive effects of platelet-rich plasma: An in vitro study on human tendon cells. Arthroscopy 2012, 28, 711-719. [CrossRef] [PubMed] 